Piotr Florencjan Szymański OFM

\title{
Nakaz miłowania Boga (Pwt 6, 4-9) w modlitwie Izraela
}

Perykopa Pwt 6, 4-9 traktująca o przykazaniu miłowania Boga ma specjalne miejsce w Księdze Powtórzonego Prawa oraz w życiu każdego Żyda. Odnosi się bowiem do pierwszego, a co za tym idzie najważniejszego pouczenia Boga udzielonego Mojżeszowi na Synaju. W pewnym sensie w tym miejscu można mówić o właściwym początku Powtórzonego Prawa. Zawiera ona fundamentalną prawdę religii żydowskiej oraz nakaz opierający się na tej prawdzie $(6,4-5)$. Chodzi o ideę wyłącznej „własności” Boga żądającego miłości od swojego narodu. Mowa jest też o relacji obu tych zagadnień we wspólnocie Izraela, gdyż „te słowa” muszą być znane między wszystkimi młodymi członkami owej społeczności (ww. 6-9). W przyszłości nic nie może być ważniejsze od obowiązku komunikowania „tych słów”. Ich przesłanie podjął na nowo Jezus w swoim nauczaniu (Mk 12, 29-30; Mt 22, 37; Łk 10, 27).

Celem niniejszego studium jest ukazanie znaczenia powyższego tekstu ze szczególnym uwzględnieniem jego roli w praktyce modlitewnej Izraela. Właśnie początkowe słowo w. 6, 4 šema' nadało nazwę słynnej modlitwie (Pwt 6, 4-9; 11, 13-21; Lb 15, 37-41 i błogosławieństwa), którą odmawiają mężczyźni dwa razy w ciagu dnia ${ }^{1}$. Fragment Pwt 6, 4-9 uznaje się za credo Izraela, w którym to Bóg zwraca się do człowieka, a nie odwrotnie.

\section{Krytyka tekstu}

Przed słowem šm ma' (w. 4) w LXX dołączono frazę wprowadzającą ${ }^{2}$.

W w. 7 zauważa się wariant odnoszący się do słowa $b^{e} \underline{b} \underline{e} t e \underline{k} \bar{a}$ (,w domu twoim”), względem którego Pięcioksiąg Hebrajsko-Samarytański i LXX posiadają wersję bez przyrostka drugiej osoby liczby pojedynczej. Owa forma z przyrostkiem jest identyczna jak w w. 11, 19a, co sugeruje wpływ tekstu paralelnego. Odnośnie do tego samego słowa LXX (Lucjana) posiada licz-

${ }^{1}$ Taki nakaz widnieje w Misznie Berakot 1, 4, natomiast Targum Neofiti wiąże pochodzenie Pwt 6, 4-9 ze śmiercią Jakuba.

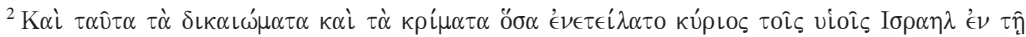

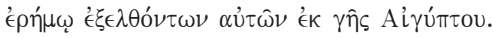


bę mnogą („domy”) stylistycznie lepiej korespondującą ze słowem $\underline{\text { badderek }}$ („w drodze”). Z wymienionych względów obie poprawki trzeba odrzucić. W tym samym wierszu widnieją również dwa warianty opuszczenia spójnika $\hat{u}$ koordynującego zdania współrzędnie. Brak go przed słowem $\underline{b}^{e} l e \underline{k} t^{e} \underline{k} \bar{a}$ („kiedy idziesz”, Pięcioksiąg Hebrajsko-Samarytański) oraz przed słowem $b^{e}$ š $\underline{k} b^{e} \underline{k} \bar{a}$ („kiedy się kładziesz spać”, Pięcioksiąg Hebrajsko-Samarytański, Wulgata oraz kilka kodeksów hebrajskich). Analogicznie jak w poprzednim przypadku widać tu wpływ miejsca paralelnego (11, 19a i 19c).

W w. 8 liczne świadectwa, w tym hebrajski kodeks z genizy kairskiej oraz Pięcioksiąg Hebrajsko-Samarytański, posiadają liczbę mnogą w stosunku do słowa jā $\underline{d} e \underline{k} \bar{a}$ („,twojej ręki”), co lepiej koresponduje z kontekstem i zapewne stanowi poprawkę stylistyczną.

W w. 9 odnośnie do słów: $\hat{u} \underline{k}^{e} \underline{t} a \underline{b} t a \bar{m}$ (,,i wypiszesz je”), bêteka a („,domu twojego") i $\hat{u} \underline{b} i s ̌ a r e \underline{k} \underline{k} \bar{a}^{3}$ (,,i na bramach twoich”) widnieją lekcje alternatywne w drugiej osobie liczby mnogiej. Są one zawarte w LXX, Pięcioksięgu Hebrajsko-Samarytańskim oraz w wersji syryjskiej. Wymienione lekcje mają charakter poprawek stylistycznych i w przypadku bêték $\bar{a}$ zmiana mogła nastąpić pod wpływem 11, 19c.

\section{Obserwacje dotyczące formy literackiej}

Ostatnie litery pierwszego i ostatniego słowa czwartego wersetu są nieco większe od pozostałych, co prawdopodobnie ma związek ze znaczeniem całej frazy, którą trzeba czytać bardzo precyzyjnie ${ }^{4}$. Wydaje się, że ów wiersz jest starszy od Dekalogu (5, 6-21), ponieważ zawiera ogólne przykazanie bez specyfikacji ${ }^{5}$.

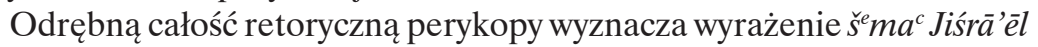
oraz tzw. setûumā' (litera sāmek oddzielajająca w. 9 od 10) wyznaczająca

${ }^{3}$ Różne kodeksy hebrajskie według Benjamina Kennicotta (np. V ${ }^{\text {Ken }}{ }^{69}$ ) opuszczają przedrostek $b^{e}$ (,w”).

${ }^{4}$ Zauważa się dwa rodzaje wyjaśnień dotyczących tego fenomenu. (1) Powiększonymi literami są 'ajin i dāleț, które łącznie tworzą słowo ‘êd (,świadek”), a zatem czytający ten tekst jest niejako „świadkiem jedności” Boga. (2) Literę dāleț łatwo pomylić z rēš, co w rezultacie mogłoby doprowadzić do tego, że zamiast słowa 'ehạa (,,jeden”) czytano by 'aher (,inny”). Zatem powiększenie litery zapobiega takiej pomyłce; por. J. H. TigAY, The JPS Torah Commentary. Deuteronomy, Fhiladelphia 1996, s. 441.

${ }^{5}$ Można się w nim dopatrzyć znaku jednoczącego różne plemiona, co jednak nie musi oznaczać, że owo przykazanie jest przeciwne pluralizmowi; por. R. E. BEE, A study of Deuteronomy Based on statistical Properties of the Text, „Vetus Testamentum” 1 (1979) t. 29, s. 7-8. 
koniec paragrafu. Natomiast jej podział rytmiczny wydaje się formować słowo hajjôm („dziš”) w w. 6 oddzielające ww. 4-6a od ww. 6b-116.

Fraza šm ma 'Jiśrā'ēl została użyta w 5, 1, aby otworzyć rozdział zawierający Dekalog, natomiast w 6, 4 początkuje dłuższą sekcję 6, 4-7, 11, która posiada odpowiednik paralelny w 9, 1-12. Jeszcze wcześniej w w. 4, 1 šmma' Jiśrā’ēl występuje łącznie ze słowem $w^{e}$ attāh(h) (,i teraz”) ${ }^{7}$. Owe trzy słowa: „słuchaj, Izraelu” $i$,teraz” konstytuują ważny znak strukturalny w pierwszej części księgi, otwierając Wielką Mowę 4-11, a szczególnie jej kluczową sekcję 4, 1-40.

\section{Orędzie šema‘}

Księga Powtórzonego Prawa wykazuje związki z nurtem mądrościowym Starego Testamentu, a szczególnie z Księgą Przysłów. Formuła początkowa šema' Jiśrā'ēl koresponduje z wyrażeniem używanym przez nauczyciela Mądrości rozpoczynającego zwykle swoje nauczanie słowami „słuchaj mój synu” (Prz 1, 8; 4, 1. 10). W miejsce „Izraela” zostaje wprowadzony „syn”, ale w perspektywie deuteronomistycznej „Izrael” jest niejako „synem dla Jahwe". Autor używa tych samych środków, co nauczyciel Mądrości przynaglający swoich uczniów do studium. Tym razem uczniem nie jest jakiś młodzieniec, lecz Izrael, a Mistrzem nie jest jeden z pisarzy, lecz sam Jahwe.

\section{Tylko Jeden Pan $(6,4)$}

Język hebrajski nie posiada trzeciej osoby czasu teraźniejszego czasownika „być” w zdaniu orzecznikowym (w znaczeniu ,jest”), dlatego termin 'ehāa (w. 4: ,jeden”) tłumaczy się na różne sposoby w zależności od rozumienia kontekstu. Generalnie jego interpretacje można podzielić na trzy grupy ${ }^{8}$ : (1)

${ }^{6}$ Por. D. L. Christensen, Deuteronomy 1-11, Dallas 1991, s. 142 (Word Biblical Commentary, 6A).

${ }^{7}$ W 10, 12 wyrażenie ,i teraz Izraelu” zostało użyte w celu otwarcia najobszerniejszej, końcowej sekcji pierwszej części fragmentu 10, 12-11, 25. Samodzielny zwrot „i teraz” został użyty po prologu historycznym $(26,1-9)$ w w. 10 stanowiącym fragment opisu prezentacji pierwszych owoców ziemi podczas święta Namiotów. W 31, 19 zwrot ten wprowadza do kantyku Mojżesza (32, 1-43).

${ }^{8}$ Por. J. G. JAnzen, On the most important Word in the Shema (Deuteronomy VI 4-5), „Vetus Testamentum” 3 (1987) t. 37, s. 280-300. 
„Jahwe jest naszym Bogiem, Jahwe jedynie” („tylko Jahwe”)9; (2) „Jahwe nasz Bóg, Jahwe jest jeden”" (3) „Jahwe nasz Bóg jest jeden Jahwe”.

Zarówno w przypadku pierwszego, jak i trzeciego tłumaczenia dostrzega się pewną aluzję do biblijnego bożka Baala, który został „rozczłonkowany” na wielu Baalim w zależności od różnych narodów i miejsc kultu ${ }^{11}$. W takim ujęciu podkreśla się aspekt polemiczny, gdyż Jahwe jest zupełnie kimś innym. Ową interpretację osłabia w. 5, zgodnie z którym nakaz miłowania Jahwe nie zakłada w pierwszym rzędzie przeciwstawienia Jahwe innym bożkom (por. 1 Krn 29, 1). Jeśli przyjmie się drugie znaczenie, wówczas cała fraza wyraża absolutny monoteizm, co jest również jednoznaczne z wyznaniem, że Bóg jest niepodzielny w sensie numerycznym ${ }^{12}$. Takie znaczenie wyklucza bliski kontekst sugerujący raczej relację względem Jahwe niż Jego naturę (w. 5).

Najbliższym myśli autora wydaje się być jednak tłumaczenie pierwsze, gdyż istotnym słowem jest zaimek osobowy „nasz” bardziej akcentujący relację Jahwe z Izraelem niż Jego naturę ${ }^{13}$. Wyraża on przede wszystkim zaproszenie do niepodzielnej miłości Jahwe ${ }^{14}$. Ów wiersz ukazuje tylko to, czego doświadczał Izrael, a mianowicie, że „Jahwe jest jego Bogiem i nikt inny”. Pośrednio jest też wyrażony protest przeciwko kultowi Baala ${ }^{15}$. Stwierdzenie „Jahwe jest jeden” jest wyznaniem wiary, że wyłącznie On będzie wzywany (Iz 2, 11. 17), co wyklucza jakikolwiek synkretyzm lub pokusę identyfikowania Jahwe z tym lub innym bóstwem lokalnym.

${ }^{9} \mathrm{~W}$ tym przypadku słowo 'ehạ $\underline{d}$ mówi o tym, czego Bóg żąda od Izraela. Takie thumaczenie wykazuje dwie wątpliwości. Pierwsza dotyczy słowa ,jedynie”, gdyż zwykle w takim przypadku biblijny język hebrajski używa $l^{e} \underline{b} a \underline{d}(2 \operatorname{Krl} 19,15$. 19; Ps 86, 10). Druga trudność jest natury syntaktycznej i dotyczy sformułowania „Jahwe jest naszym Bogiem”, które wprawdzie jest możliwe (2 Krn 13, 10), lecz rzadkie w Starym Testamencie, a w Księdze Powtórzonego Prawa - wyjątkowe (por. J. H. Tigay, The JPS Torah Commentary. Deuteronomy, dz. cyt., s. 439).

${ }^{10} \mathrm{~W}$ tym wypadku słowo 'ehạa $\underline{d}$ mówi coś o samym Bogu. Takie tłumaczenie jest również problematyczne, gdyż drugie słowo Jahwe wydaje się zbędne, a w jego miejscu można by się raczej spodziewać określenia 'Elōhîm („Pan”).

${ }^{11}$ Wymienia się także analogie do innych bożków: Isztar, Set, Re itp. (por. J. H. TigaY, The JPS Torah Commentary. Deuteronomy, dz. cyt., s. 439).

${ }^{12}$ Wyraźną deklarację monoteizmu widać w 4, 35 („poza Nim nie ma innego”) i w 4, 39 („na niebie wysoko i na ziemi nisko nie ma innego”).

${ }^{13}$ Por. J. H. TigaY, The JPS Torah Commentary. Deuteronomy, dz. cyt., s. 76.

${ }^{14}$ Por. też Pwt 10, 12; 11, 1; 13, 4; 19, 9; 30, 6. 16. 20; Jdt 5, 31.

${ }^{15} \mathrm{~W}$ tym kontekście bardzo wymowny jest tekst paralelny Za 14, 9b: „Wówczas Pan będzie jeden i jedno będzie Jego Imię". 


\section{CAŁKOWITE ODDANIE $(6,5)$}

Użyte w w. 5 słowo „kochać” stosuje się również w Starym Testamencie na określenie przyjaźni (1 Sm 16, 21; 18, 1), miłości małżeńskiej (Rdz 24, 67) lub względem dzieci ( $\mathrm{Rdz} 22,2 ; 37,3)$. Być może autor miał na myśli obraz z Księgi Ozeasza, gdzie Izrael jest ukazany w obrazie „małżonki” Jahwe miłującej wyłącznie swojego męża $(3,1)$. W świetle takiej perspektywy Bóg żąda od człowieka całkowitego oddania (Pwt 4, 29; 2 Krl 23, 25). Pragnie zdobyć jego serce i zająć w nim uprzywilejowane miejsce. Na tej podstawie wyrasta między przymierzem z Jahwe i miłością małżeńską paralelizm, który szeroko rozwinięto w księgach prorockich (Oz 2, 4-9; Jr 3, 6-8; Iz 50, 1). Podobna idea miłości powraca często w Księdze Powtórzonego Prawa (10, 12; 11, 1-22).

Potrójne wyrażenie „posiadania” zamieszczone w w. 5 kładzie nacisk na miłość „totalną” ku Panu. „Serce” (lēb zwykle odnosi się do wnętrza człowieka, „miejsca jego myśli, intencji i uczuć” ${ }^{16}$, zaś „dusza” (nepeš) do „siedziby jego emocji, pasji i pragnień" ${ }^{17}$. Ostatnia fraza $\left(b^{e} \underline{k} o l-m^{e}{ }^{\prime} \underline{d} \underline{k} \underline{k} \bar{a}\right)$ nadaje poprzednim określeniom emfazę najwyższego stopnia. Zrobić coś z „całej mocy” oznacza uczynić to „w sposób nieograniczony, nadzwyczajny, wyjątkowy, całkowity"18.

Egzegeza rabinacka trzech określeń miłości aplikuje je do konkretnych zachowań $^{19}$. Zważywszy, że „serce” czasami odnosi się do „intencji”, „kochać z całego serca" oznacza włączenie wszystkich inklinacji tkwiących w człowieku, zarówno tych dobrych, jak i złych ${ }^{20}$. Nepeš odnosi się też do „życia” (Pwt 19, 6. 11.21), dlatego nakaz miłowania „,z całej duszy” domaga się najwyższej „,eny własnego życia” (1 Krl 2, 23). Trzecie określenie $m^{e}$ 'o $\underline{d}$ oznacza też „własność” i „siłę”, co thumaczy się, że „nawet za cenę zdrowia i dobytku”21.

Trzeba zauważyć, że powyższe określenia nie dotyczą miłości w znaczeniu emocjonalnym, lecz chodzi bardziej o akty działania, bowiem gdy Bóg kocha,

${ }^{16}$ Por. Pwt 8, 2; 15, 9-10; 19, 6; 28, 47; 29, 3; Lb 15, 39; 2Krl 5, 26; Jr 3, 15; 1Krn 12, 38.

${ }^{17}$ Por. Pwt 12, 20; 23, 25; 24, 15; Rdz 23, 8; 34, 3; 44, 30.

${ }^{18}$ Jest to idiom, który w tym miejscu pojawia się w Biblii po raz pierwszy. Drugi raz występuje w $2 \mathrm{Krl}$ 23, 25, charakteryzując króla Jozjasza, który powrócił do Boga w niespotykanym dotąd u innych władców stopniu. Czasami zwrot ten porównuje się do częstszej frazy bim'ō $\underline{d} m^{e}$ 'o $\underline{d}$ („,bardzo, bardzo dużo”). Ze względu na bliski kontekst wyrażenia „,z całego serca i duszy” ów idiom nie może odnosić się do „posiadłości” czy „majątku”, gdyż winien mieć porównywalne znaczenie (por. J. H. TigaY, The JPS Torah Commentary. Deuteronomy, dz. cyt., s. 358, p. 18).

${ }^{19} \mathrm{Na}$ ten temat zob. Targum Jonatana; Sifrei 32.

${ }^{20}$ Czytany w synagodze tekst posiada lekcję alternatywną zawartą w Targumie Jonatana odnośnie do Pwt 6, 5, w której wzywa się do miłości Jahwe wraz z dwiema skłonnościami serca i z wszystkimi bogactwami; por. też: Pwt 12, 20; 23, 25; 24, 15; Rdz 23, 8; 34, 3; 44, 40.

${ }^{21}$ Por. J. H. TigaY, The JPS Torah Commentary. Deuteronomy, dz. cyt., s. 358, p. 21. 
znaczy to, że dobrze czyni (Pwt 7, 8; 23, 6) 22. W takim kontekście łatwiej wyjaśnić pewne zakłopotanie wywołane obwarowaniem miłości przykazaniem, gdyż zwykle myśli się o niej w kategoriach dobrowolności i spontaniczności bezżadnego przymusu widocznego bez wątpienia w w. 5. Wyjaśnia tę kwestię 10, 12, gdzie wyraźnie widać, iż miłość do Boga oznacza wierność i lojalność wobec Jego przykazań (por. 7, 9; 11, 1). Winna się ona wyrażać w pokornej służbie (por. 11, 22; 19, 9) łączącej się z pobożnością i posłuszeństwem²3.

W świetle dotychczasowych obserwacji widać, że odpowiedź na pytanie, co to znaczy kochać Boga „całym sercem”, różni się od popularnej opinii, według której większość ludzi opisuje serce jako władzę odczuwania lub czynienia czegoś z uczuciem. Takie zrozumienie opiera się na idei głoszącej, że uczucia reprezentują samo centrum człowieka, sedno jego bytu. Jak już zauważono, w Biblii hebrajskiej „serce” jest postrzegane nieco inaczej: jako miejsce podejmowania fundamentalnych wyborów. W konsekwencji może ono dokonać wyboru kochania Boga. Jest ono czymś podstawowym, ponieważ każda inna decyzja, wybór czy osąd oparte zostaną na nim. Spojrzenie biblijne zakłada osobiste oddanie przez szukanie Boga przede wszystkim i nade wszystko. Tę decyzję popularnie określa się jako „stawianie Go na pierwszym miejscu”, co w praktyce wiąże się z posłuszeństwem wobec Niego. Z opisów biblijnej historii narodu wybranego wynika, że z jednej strony Izraelowi łatwiej było zostać posłusznym, gdy zdecydował się postawić Boga na pierwszym miejscu, z drugiej zaś strony, nie zawsze łatwo było pozostać posłusznym.

Również Jezus definiował miłość w tych kategoriach: „Jeżeli Mnie miłujecie, będziecie zachowywać Moje przykazania” (J 14, 15). Noc w Getsemani była Jego osobistą walką wewnętrzną, w czasie której nie przyszło Mu łatwo zaakceptować to, do czego wezwał Go Ojciec. Był posłuszny, mimo iż było to trudne. Owa trudność nie oznaczała, że kochał mniej, lecz sprawiła, iż Jego miłość stała się bardziej widoczna. Trzeba też zaznaczyć, iż w perspektywie biblijnej istnieje różnica między posłuszeństwem niewolnika wynikającym z lęku przed karą a posłuszeństwem syna wyrażającym miłość z serca opartą na oddaniu.

Miłość wobec Boga wymaga czegoś więcej niż trzymania się szeregu wskazówek, praw czy zasad. Jest to głębokie i całkowite oddanie się komuś, działania.

${ }^{22}$ Hebrajskie słowa wyrażające emocje określają je jako działanie lub jako rezultat

${ }^{23}$ Takie użycie słowa „miłować” wykazuje związki z terminologią polityczną stosowaną na Bliskim Wschodzie, gdzie miłość rozumiano jako lojalność wobec podmiotu władzy. Księga Powtórzonego Prawa jako pierwsza wspomina o miłości Boga, gdyż wcześniejsze pisma akcentują raczej poddanie i szacunek (por. J. H. TigaY, The JPS Torah Commentary. Deuteronomy, dz. cyt., s. 77). 
a nie czemuś. Pismo Święte podkreśla jej osobową naturę, opisując ją w odniesieniu do ludzkich relacji: ojciec i syn, mąż i żona, bracia oraz przyjaciele. Owa relacja osobowa z wszechmogącym Bogiem wypływa z wezwania Mojżesza po imieniu ( $\mathrm{Wj} 3,4)$ oraz z objawienia mu imienia Jahwe „JESTEM, KTÓRY JESTEM” (w. 14). Jezus pogłębił tę więź na płaszczyźnie duchowej, udzielając Kościołowi Ducha Świętego (J 16, 7). W relacji osobowej trzeba zejść w wymiar duchowy i poznać Boga przez moc Jego Ducha. W praktyce osobiste oddanie łączy się z oddawaniem Mu czci $(\mathrm{Rz} 12,1)$.

Stwarzając człowieka na swój obraz, Bóg uzdolnił go do myślenia. Z punktu widzenia Boga dobry umysł niekoniecznie musi być niezwykle inteligentny, lecz winien stanowić dobre narzędzie do kochania Go. W świetle powyższego przykazania Bóg daje wskazania nie tylko odnośnie do tego, co trzeba robić, ale również jak należy myśleć. To można wypełnić dzięki przylgnięciu do słowa Bożego stanowiącego klucz do miłowania Go umysłem (1 Tes 2, 13).

Trzeci człon przykazania przypomina, iż dla Boga „wszystko” znaczy „wszystko bez wyjątku”. Ma to być relacja całkowitego oddania, w której nic nie zostało zatrzymane. Zapewne chodzi tu również o czas i środki dane człowiekowi do dyspozycji. Czas i dobra są najbardziej powszechnymi zasobami, które razem tworzą dużą „porcję mocy” człowieka (2 Kor 8, 1-4).

\section{Pwt 6, 4-9 w codziennej modlitwie šrma' Jiśrā'ēl}

Jak już wspomniano we wstępie, perykopa Pwt 6, 4-9 zajmuje ważne miejsce w codziennej modlitwie pobożnego Żyda. Fragment 6, 6-8 został powtórzony w 11, 18-20.

\section{WYMIAR WEWNĘTRZNY $(6,6)$}

Według wspomnianej konstrukcji tekstu na jego podział rytmiczny może wpływać słowo hajjôm („dziś”) w w. 6 oddzielające ww. 4-6a od ww. 6b-9. Wraz z frazą šema' Jiśrā'ēl słowo to konstytuuje ważny znak strukturalny w księdze i analizowanym fragmencie. Werset szósty podsumowuje czwarty i piąty, akcentując aktualne działanie („dziś”) związane z interioryzacją usłyszanego orędzia. Chodzi o akt wewnętrznego przylgnięcia do słowa Bożego, aby nastąpiło swoiste „przejście” od tego, co płynie z zewnątrz, do „zakotwiczenia” usłyszanej treści w sercu słuchacza. Analogicznie jak na początku w. 4, autor zachowuje się jak nauczyciel Mądrości, który najpierw nakłania ucznia do posłuszeństwa (,słuchaj mój synu” - Prz 1, 8; 4, 1. 10), aby następnie utrwalić materiał w jego sercu $(3,1 ; 4,4 ; 6,21 ; 7,3)^{24}$.

${ }^{24}$ Podobny model dydaktyczny w relacjach nauczyciel-uczeń, ojciec-syn, pan-wasal można znaleźć w literaturze pozabiblijnej (Egipt i Hetyci) i wielu miejscach Starego Testamentu 
Posługiwano się stereotypową frazą polecającą recytację lub zanotowanie instrukcji dotyczących przykazań25: „niech pozostaną te słowa, które dziś tobie nakazuję, w twoim sercu” (w. 6). Związek z prawem deuteronomicznym wykazuje zwłaszcza sformułowanie: „te słowa, które dzisiaj tobie nakazuję" (por. 12, 28).

\section{WYMIAR ZEWNĘTRZNY $(6,7-9)$}

Orędzie zawarte w ww. 4-6 winno być „,wpojone” (literalnie „powtarzane”) dzieciom (w. 7), gdyż każdy, kto studiuje Torę, jest zobowiązany nauczać swoich domowników ${ }^{26}$. Kontrastujące ze sobą frazy w w. 7 oznaczają, iż nauczanie dotyczy każdego miejsca i całego czasu (Prz 6, 21-22). Do tego trzeba też dołączyć wyraz zewnętrzny, czyli ręce i oczy (w. 8). Cała osoba musi się zaangażować, aby przyjąć słowo Boże. Poznaniu zasadniczej prawdy wiary musi odpowiadać specjalne zaangażowanie i zachowanie względem Boga.

Ideę w. 6 zawiera też 11, 18 oraz Wj 13, 9. 16. Między Pwt 6, 8 i 11, 18 dostrzega się drobne różnice, gdyż występują w nich dwa odmienne czasowniki: „będą” $(6,8)$ i „przywiążecie je” $(11,18)$. Przytwierdzone do ręki słowa Pana oznaczają wszystkie przykazania Prawa, natomiast w Wj 13, 9 i 16 chodzi o zachowanie partykularnego rytu - „znaku” na ręce i „pamiątki” między oczami, które oznaczają przynależność do kultu.

W Pwt 6, 8 jest mowa o „znaku przytwierdzonym do ręki i na środku czoła”, co pozwala wykazać związek ze zwyczajem trwającym do dzisiaj ${ }^{27}$. Żydzi zaczęli rozumieć powyższe słowa w sposób literalny, dlatego perykopy Wj 13, 1-10. 11-16; Dt 6, 4-9 i 11, 13-21 spisane na małych pergaminach wkładano do kasetki ze skóry, aby następnie przytwierdzić je do ręki i na czoło w czasie modlitwy porannej. Hebrajskie słowo tọt $\bar{a} p \bar{p} \underline{t}$ zostało przetłumaczone w Targumie Jonatana jako tepillîn. Pierwotnie nawiązywało do „stygmatu” lub „przepaski” (por. arabskie tata) i odnosiło się do Wj 13, 16 , gdzie bardziej dostrzega się sens figuratywny. Określenie $t^{e}$ pillîn pochodzi od rdzenia pll („odłączyć, rozdzielić”) bądź tfl („przywiązać, przymocować”). Nakładając tepillîn, każdy Żyd świadczy przed światem, że jest „oddzielony” od innych narodów. Taki wymiar podkreślali zwłaszcza

(Ps 1, 2; 40, 9; 119, 11. 16); por. J. H. TIGAY, The JPS Torah Commentary. Deuteronomy, dz. cyt., s. 358, p. 22 i 23.

${ }^{25}$ Por. Pwt 4, 2. 40; 6, 1-2; 19, 9; 28, 1. 14. 15.

${ }^{26}$ Analogiczne nakazy widnieją w babilońskim opowiadaniu o stworzeniu świata Enuma Elisz. Akcentuje się w nim obowiązek uczenia dzieci imienia boga Marduka (por. J. H. TigAY, The JPS Torah Commentary. Deuteronomy, dz. cyt., s. 78).

${ }^{27}$ Targum Jonatana $\mathrm{Wj}$ 13, 9.16 potwierdza taką interpretację tych tekstów w czasach Nowego Testamentu. Według niego filakterie są znakiem upamiętniającym wyjście z Egiptu (za: F. MAnns, La preghiera d'Israele al tempo di Gesù, Bologna 1996, s. 120). 
faryzeusze, dla których oznaczało to odmienny sposób „świętego” życia. Ze wspomnianym czasownikiem pll łączy się też słowo $t^{e}$ pilla $(h)$ oznaczające „modlitwę". Z tego względu zakłada się filakterie jedynie w celu modlitwy. Przymocowując je do głowy, wyznaje się jedność z Bogiem poprzez rozum, zaś umiejscowienie ich na lewej ręce oznacza włączenie do celebracji aktywnej sfery działania. W ten sposób filakterie wyrażają równowagę między kontemplacją i działaniem. Autor podją tę antyczną tradycję jako symbol bezwarunkowej przynależności Izraelitów do swego Boga ${ }^{28}$.

Warto też wspomnieć o symbolice wykonania i nakładania samych filakterii. Są to dwie kasetki ze skóry z przytwierdzonymi do nich rzemykami słu żącymi do przywiązania ich do lewej ręki oraz głowy. Wewnątrz obu pojemników umieszcza się uformowany kawałek skóry w ten sposób, aby utrzymał cztery pergaminy z wyżej wymienionymi tekstami. Są one zwinięte w rulonik i spięte włosem cielęcym symbolizującym zasługi człowieka przychodzącego ze wschodu, aby ofiarować imieniu Boga tłustego cielca ${ }^{29}$. Cztery manuskrypty są przykryte pergaminem przytwierdzonym do skóry pojemnika dwunastoma punktami. W tym dostrzega się aluzję do dwunastu pokoleń Izraela $^{30}$. Podczas wytwarzania wspomnianej kasety ze skóry na jej ściance lewej i prawej wypisuje się dwie litery šîn z trzema i czterema drążkami nad nimi. Niektórzy twierdzą, iż owe trzy drążki oznaczają świętość Boga według Iz 6, zaś cztery drążki odnoszą się do czterokrotnej recytacji modlitwy Qaddisz. Inni widzą w tym trzech ojców (Abrahama, Izaaka, Jakuba) i cztery matki Izraela (Sarę, Rebekę, Rachelę, Leę) $)^{31}$. Poza tym, mówi się o symbolice dwóch liter šin , które w sumie reprezentują liczbę 600. Połączone dwie litery šîn formują słowo šěš („sześć”). Gdy do 600 i 6 doda się siedem drążków otrzymujemy liczbę 613, która oznacza liczbę przykazań Tory.

Również sposób nakładania filakterii jest ustalony. Najpierw przymocowuje się je na lewą rękę, gdyż łatwiej można je potem przycisnąć z lewej strony do serca ${ }^{32}$. Filakterie zostają przymocowane do ręki za pomocą wspo-

${ }^{28}$ Por. M. CALOz, Exode, XIII, 3-16 et son rapport au Deutéronome, „Revue Biblique” 75 (1968), s. 51-53.

${ }^{29}$ Por. Targum Jonatana Kpł 22, 27.

${ }^{30} \mathrm{~W}$ czasach Nowego Testamentu pergamin z Dekalogiem znajdował się obok Pwt 6, 4-9. Potwierdza to Sanhedryn 11, 3, Papirus Nash oraz filakterie z Qumran (za: J. ManN, Changes in the Divine Service of the Synagogue due to religious Persecutions, „Hebrew Union College Annual" 4 (1927), s. 191-292).

${ }^{31}$ Por. Targum Neofiti Kpł 22, 27.

${ }^{32}$ Rabini twierdzą, iż użyty termin jādek $\underline{k} \bar{a}$ (,ręka twoja”) można odczytać jād $k \bar{e} h \bar{a}(h)$, co znaczy „ręka słaba” (por. F. MAnns, La preghiera..., dz. cyt., s. 122). 
mnianych rzemyków, którymi ręka jest owinięta siedem razy ${ }^{33}$. Następnie wkłada się kasetę między palce, tworząc literę šin, która tym razem oznacza Šaddaj. Filakterii można używać jedynie w ciągu dnia poza szabatem, gdyż ów dzień jest znakiem sam w sobie, a znaków nie wolno mnożyć. Poza tym trzeba w szabat wystrzegać się wszelkiej pracy, nawet noszenia filakterii ${ }^{34}$.

Dwa fragmenty Księgi Powtórzonego Prawa (6, 4-9 i 11, 13-21) umieszcza się też w metalowej rurce, aby następnie przytwierdzić ją do drzwi domów lub poszczególnych pokoi. Antyczni Egipcjanie również umieszczali błogosławieństwa w drzwiach, podobnie też czynili arabowie z tekstami Koranu. Miało to służyć lepszemu zapamiętaniu poleceń Boga, a także pełniło funkcję ochronną, niczym amulety przeciwko złym duchom. U Żydów jest to tzw. mezuza, której dotyka się, przechodząc przez drzwi.

W świetle powyższych obserwacji można stwierdzić, że perykopa Pwt 6, 4-9 zawiera pięć szczegółowych przykazań: (1) miłość Boga; (2) nauczanie przepisów Prawa własnych dzieci; (3) mówienie o Prawie przy każdej okazji; (4) posługiwanie się filakteriami i (5) mezuzą. Można też zauważyć pewien paradoks zawarty w analizowanym tekście, który jest również widoczny w całej tradycji Izraela. Otóż wielokrotnie materializuje się rzeczywistość typowo duchową. Modlitwa niejako posiada potrzebę wsparcia ze strony przedmiotów materialnych.

Wronki

PIOTR FLORENCJAN SZYMAŃSKI OFM

\section{Sommario}

Ordine di amare Dio (Dt 6, 4-9) nella preghiera d'Israele

Il testo di Dt 6, 4-9 contiene cinque precetti: quello di amare Dio, di insegnare la Legge ai propri figli, di parlare della Legge quando si presenta l'occasione, di mettere i filatteri sulla mano e sulla fronte e la mezuzah agli stipiti delle porte.

È un tipico paradosso di Israele quello di incarnare, di materializzare ciò che è spirituale. La preghiera ha bisogno di supporti materiali. I filatteri che la Bibbia ordina agli ebrei di portare ne forniscono un chiaro esempio. L'ebraismo si ricorda che l'uomo è un composto complesso che ha bisogno di segni per prepararsi all'incontro con Dio.

${ }^{33}$ Cyfra siedem posiada kilka interpretacji. Mówi się o siedmiu słowach fragmentu Ps 145, 16 wspominającego o ręce Boga. Wspomina się też siedem błogosławieństw wygłoszonych podczas małżeństwa, co jest aluzją do godów Boga ze swoim ludem, gdyż podczas zakładania filakterii na rękę recytuje się fragment Oz 2, 21-23 (F. MANns, La preghiera..., dz. cyt., s. 122).

${ }^{34}$ Zob. Menahot 36b; Rosh ha-shanah 29b; Sukkot 42b-43a; Meghillah 4b. 